\title{
PENERAPAN MODEL PEMBELAJARAN KOOPERATIF TIPE STUDENT TEAM ACHIEVEMENT DIVISIONS (STAD) UNTUK MENINGKATKAN MOTIVASI DAN HASIL BELAJAR IPA SISWA KELAS V B SDN 047 TARAKAN
}

\author{
Rudi Pujiono1, \\ ${ }^{1}$ Fakultas Keguruan dan Ilmu Pendidikan Universitas Borneo Tarakan
}

\begin{abstract}
Abstrak
Implementation of Cooperative Learning Model Type Student Team Achievement Divisions (STAD) To Improve Motivation and Learning Results of Science Class V Students B SDN 047 Tarakan. Elementary School Teacher Education Study Program, Teacher Training and Education Faculty, Tarakan Borneo University. Guided by Kadek Dewi Wahyuni Andari and Agustinus Toding Bua. The purpose of this study is to improve the motivation and learning outcomes of science with the Application of Cooperative Learning Model Type Student Team Achievement Divisions (STAD) in Class V B SDN 047 Tarakan. The type of research used is Classroom Action research conducted at SDN 047 Tarakan in second semester of academic year 2016/2017. The subjects of the study were students of class V-B SDN 047 Tarakan amounted to 32 male students totaling 18 students and 14 students. The results of this study obtained the cognitive aspects of the first cycle of $56.25 \%$ and then in the second cycle increased by $87.5 \%$, On the affective aspects of cycle I of $50 \%$ and then in the second cycle increased by $84.375 \%$. On the psychomotor aspect of cycle I of $68.75 \%$ then in cycle II increased by $87.5 \%$, On the Motivation learning cycle I of $62.5 \%$ and then in the second cycle increased by $84.375 \%$. So it can be said that the research has been successful and in accordance with success indicators.
\end{abstract}

\author{
Keywords: \\ learning motivation, \\ learning outcomes, \\ cooperative learning \\ model Type Student \\ Team Achievement \\ Divisions (STAD)
}

\section{PENDAHULUAN}

Pendidikan merupakan aspek yang paling mendasar dalam pembangunan kehidupan suatu bangsa. Peran pendidikan sangat penting untuk menciptakan generasi yang cerdas, terbuka, dan demokratis, pendidikan merupakan dasar pertumbuhan dan perkembangan dalam kehidupan manusia, melalui pendidikan manusia dapat meningkatkan kepribadian, pengetahuan, dan membentuk karakteristik manusia. Pendidikan memegang peran penting dalam rangka meningkatkan kualitas sumber daya manusia, sehingga pendidikan sekolah dasar menjadi dasar utama untuk menuju jenjang pendidikan berikutnya. Pendidikan merupakan suatu upaya untuk mengembangkan potensi yang ada dalam diri siswa melalui usaha sadar yang dilakukan secara terus menerus dan terencana.

Pelajaran ilmu pengetahuan alam merupakan suatu proses belajar mengajar yang dibangun oleh guru untuk mengembangkan kreativitas berpikir siswa yang dapat meningkatkan kemampuan berpikir siswa, serta dapat meningkatkan kemampuan mengkonstruksi pengetahuan baru sebagai upaya meningkatkan penguasaan yang baik terhadap materi ilmu pengetahuan alam. Berdasarkan hasil observasi dan wawancara yang dilakukan oleh peneliti dengan guru kelas V B SDN 047 Tarakan didapatkan informasi bahwa nilai UAS kelas V B pada semester ganjil tahun pelajaran 2016/2017 dengan presentase ketuntasan untuk mata pelajaran Ilmu Pengetahuan Alam yaitu 18 siswa dengan presentase (56,25\%) dengan KKM 65, sedangkan siswa tidak tuntas 14 siswa dengan presentase $(43,75 \%)$, Rendahnya motivasi dan hasil belajar siswa V B SDN 047 Tarakan pada mata pelajaran Ilmu Pengetahuan Alam, disebabkan ada beberapa masalah yang timbul dalam kegiatan pelaksanaan pembelajaran Ilmu Pengetahuan Alam, yaitu: (1) guru masih menggunakan metode konfensional, (2) kurangnya motivasi belajar siswa dan kurangnya perhatian dari orang tua siswa, (3) kondisi lingkungan sekolah yang berada 
di wilayah pesisir, (4) siswa kurang aktif selama mengikuti kegiatan belajar mengajar. Berdasarkan permasalahan yang dihadapi maka peneliti memberikan solusi dengan menerapkan model pembelajaran kooperatif tipe STAD dapat meningkatkan motivasi dan hasil belajar IPA siswa kelas V B SDN 047 Tarakan.

Proses pembelajaran Ilmu Pengetahuan Alam yang cepat dan inovatif dari seorang guru sebagai fasilitator dan mediator pembelajaran dikelas, agar dapat meningkatkan motivasi dan hasil belajar siswa. Dalam upaya untuk meningkatkan motivasi dan hasil belajar siswa pada mata pelajaran Ilmu Pengetahuan Alam, maka peneliti memberikan alternatif yaitu penguasaan materi, keaktifan siswa, memberikan motivasi hendaknya dalam pembelajaran Ilmu Pengetahuan Alam perlu di terapkan serta menggunakan model pembelajaran yang sesuai dangan materi pembelajaran. Model pembelajaran kooperatif tipe STAD, telah sesuai digunakan pada pembelajaran Ilmu Pengetahuan Alam kelas V B SDN 047 Tarakan, karena melibatkan siswa bekerja sama secara aktif, inovatif, kreatif, dan menyenangkan. Tujuan peneliti menggunakan model pembelajaran kooperatif tipe STAD untuk meningkatkan motivasi dan hasil belajar IPA siswa kelas V B SDN 047 Tarakan.

Penggunaan model pembelajaran kooperatif tipe STAD memiliki manfaat diantanya: Bagi guru, meningkatkan kemampuan yang dimiliki guru dalam proses belajar mengajar serta menjadikan siswa lebih aktif dan termotivasi dalam belajar dan memberikan pengetahuan cara belajar dengan menggunakan model pembelajaran kooperatif tipe STAD sehingga tujuan pembelajaran diharapkan dapat tercapai. Slavin (2005:144) menyatakan bahwa STAD, siswa ditempatkan dalam tim belajar beranggotakan 4-5 orang siswa yang merukan canmpuran menurut tingkat prestasi, jenis kelamin, dan suku. Guru menyajikan pembelajaran, dan kemudian siswa berkerja dalam tim mereka memastikan bahwa seluruh anggota tim telah mrnguasai materi tersebut. Kemudian, seluruh siswa diberikan tes tentang materi tersebut, pada saat tes mereka tidak diperbolehkan saling membantu. STAD terdiri atas lima komponen utama, yaitu presentasi kelas, tim, kuis, skor, kemajuan individual dan rekognisi (penghargaan) tim.

Motivasi dipandang sebagai suatu proses yang ditandai adanya reaksi untuk mencapai suatu tujuan sedangkan Kata motif, diartikan sebagai daya upaya yang mendorong seseorang untuk melakukan sesuatu. Motif dapat dikatakan sebagai daya penggerak dari dalam dan di dalam subyek untuk melakukan aktivitas-aktivitas tertentu demi mencapai suatu tujuan. Motif menjadi aktif pada saat tertentu, terutama bila kebutuhan mencapai tujuan sangat dirasakan atau mendesak. Menurut Donald, (dalam Sardiman, 2014:73) motivasi adalah perubahan energi dalam diri seseorang yang ditandai dengan munculnya "feeling" dan didahului dengan tanggapan terhadap adanya tujuan. Setiap individu yang belajar tentunya memiliki tujuan dan hasil, dalam mencapai sebuah hasil yang baik dapat dilakukan dengan usaha dan kerja keras agar mendapatkan hasil yang memuaskan. Keberhasilan seorang siswa dalam pembelajaran dikatakan tuntas atau berhasil ketika dapat mencapai kriteria ketuntasan minimal (KKM). Menurut Abrurrahman (dalam Jihad, 2012:14) hasil belajar merupakan kemampuan yang didiperoleh anak setelah melalui kegiatan belajar. Belajar itu sendiri merupakan suatu proses dari seseorang yang berusaha untuk memperoleh suatu bentuk perubahan prilaku yang relatif menetap. peneliti melakukan penelitian tindakan kelas (PTK) dengan judul "Penerapan Model Pembelajaran Kooperatif Tipe Student Team Achieviement Divisions(STAD) Untuk Meningkatkan Motivasi Dan Hasil Belajar IPA Siswa Kelas V B SDN 047 Tarakan".

\section{METODE PENELITIAN}

Jenis penelitian yang digunakan adalah penelitian tindakan kelas (PTK). Arikunto (2012: 2) Penelitian Tindakan Kelas (PTK) adalah penelitian tindakan (Action Research) yang dilakukan dengan tujuan untuk mengembangkan ketrampilan guru berdasarkan pada persoalan-persoalan yang terjadi dalam pembelajaran, dan diharapkan dapat meningkatkan kualitas pembelajaran. Arikunto (2012: 16) mengemukakan dalam setiap siklus terdapat empat tahapan kegiatan, diantaranya: 1) Perencanaan, 2) Pelaksanaan, 3) Pengamatan (observasi), dan 4) Refleksi. Secara lebih detail, prosedur kerja penelitian disajikan dalam skema berikut: 


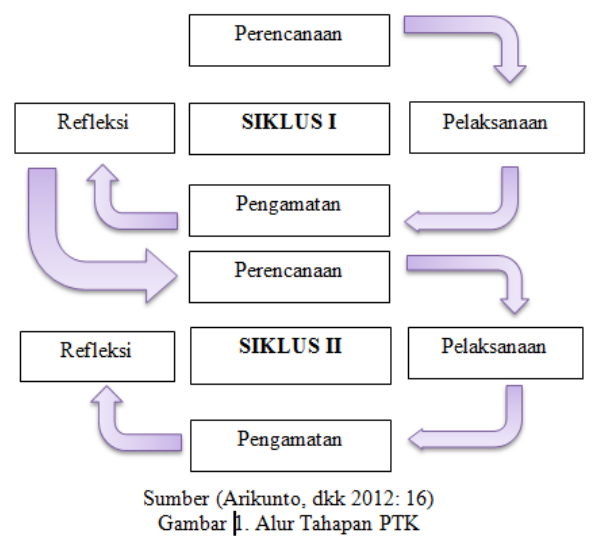

Penelitian dilaksanakan di SDN 047 Tarakan yang berlokasi di Jalan Tanjung Pasir Rt. 21 mamburungan, Kecamatan Tarakan Timur, pada semester ganjil tahun pembelajaran 2016/2017. Subjek dalam penelitian ini adalah siswa kelas V B SDN 047 Tarakan tahun pembelajaran 2016/2017 dengan jumlah siswa 32 siswa. Terdiri dari 18 siswa laki-laki dan 14 siswa perempuan.

Pada penelitian ini instrumen untuk pengambilan data yang digunakan adalah teknik tes, non tes, teknik tes yaitu penilaian kognitif (tes hasil belajar), teknik nontes yaitu, penilaian motivasi belajar, lembar penilaian afektif dan lembar penilaian psikomotorik, serta lembar observasi aktivitas guru, lembar observasi aktivitas siswa. Pada penelitian ini teknik analisa data yang digunakan adalah sebagai berikut:

1. Tes

Penilaian kognitif

Ketuntasan belajar siswa (individual) dapat dihitung dengan menggunakan rumus:

Nilai $=\frac{\text { Skor yang diperoleh }}{\text { Skor maksimal }} \times 100$

2. Non Tes

Penilaian motivasi belajar, Penilaian afektif, Penilaian psikomotorik, Penilaian Lembar Observasi Aktivitas Siswa, dan Penilaian Lembar Observasi Aktivitas Guru dalam Pembelajaran di Kelas, dapat dihitung dengan menggunakan persamaan sebagai berikut:

Nilai $=\frac{\text { Skor } \text { yang diperoleh }}{\text { Skor maksimal }} \times 100$ (Purwanto, 2013: 207)

3. Menentukan keberhasilan belajar secara klasikal

Rumus yang digunakan untuk mengetahui keberhasilan belajar siswa secara klasikal adalah sebagai berikut:

$$
\mathrm{P}=\frac{\sum n_{1}}{n} \times 100 \%
$$

Keterangan:

P : Nilai ketuntasan belajar

$\sum \mathrm{n} 1$ : Jumlah siswa tuntas belajar secara klasikal

$\mathrm{N}$ : Jumlah total siswa

Selanjutnya dari hasil penilaian afektif, psikomotorik, lembar penilaian siswa, dan guru mengkategorikan berdasarkan rentang nilai yang dapat dilihat pada Tabel 1 berikut.

Tabel 1. Hasil Penilaian Afektif, Psikomotorik,Lembar Penilaian Siswa Dan Guru

\begin{tabular}{lll}
\hline Nilai & Huruf & Kategori \\
\hline $80-100$ & A & Sangat Baik \\
$66-79$ & B & Baik \\
$56-65$ & C & Cukup \\
$40-55$ & D & Kurang \\
$30-39$ & E & Sangat Kurang \\
\hline
\end{tabular}




\section{ANALISIS DAN PEMBAHASAN}

Penelitian yang dilakukan di SDN 047 Tarakan mendapatkan data yaitu: Pertama pada aspek aktivitas siswa masih terdapat siswa yang tidak lengkap membawa perlengkapan, peneliti nasehati siswa untuk mengecek perlengkapan sebelum berangkat sekolah. Kemudian masih banyak siswa yang belum patuh dan tertib di dalam kelas, hal ini disebabkan masih banyak siswa yang bermain dengan temannya, peneliti memberikan nasehat untuk tidak bermain di dalam kelas karena akan menggagu teman yang lain yang sedang belajar. Kemudian masih banyak siswa belum memahami proses pembelajaran dengan menerapkan Model Pembelajaran Kooperatif Tipe STAD peneliti menjelaskan langkah-langkah Model Pembelajaran Kooperatif Tipe STAD . Kemudian masih banyak yang tidak aktif mengajukan pertanyaan kepada guru. Hal ini disebabkan siswa malu mengajukan pertanyaan kepada guru, peneliti menjelaskan pentingnya bertanya dari materi yang belum di pahami dan melatih kepercayaan diri siswa untuk bertanya dengan cara memberikan pertanyaan kepada siswa dan siswa mengangkat tangan seblum menjawab pertanyaan. Selanjutnya masih banyak siswa yang hanya mengerjakan LKS secara individu. Hal ini di sebabkan siswa belum terbiasa dalam bekerja sama dalam kelompok, peneliti membimbing diskusi kelompok menjelaskan bagaimana cara kerja kelompok yang baik.

Kedua pada aspek aktivitas guru, dalam Penerapan Model Pembelajaran Kooperatif Tipe STAD guru kurang menanyakan keadaan siswa serta memotivasi siswa dalam memulai kegiatan pembelajaran, Peneliti akan memberikan motivasi belajar sebelum melaksanakan pembelajaran. Selanjutnya guru kurang tepat waktu dalam memulai pembelajaran dikarenakan pukul 07.15-08.45 WITA siswa melaksakan Olahraga dan tidak tepat waktu dalam mengakhiri kegiatan pembelajaran. Peneliti mendiskusikan kepada wali kelas setelah kegiatan olahraga diharapkan siswa cepat mengganti baju dan masuk dalam kelas, Kemudian guru juga belum mampu dalam menjaga ketenangan kelas dan menumbuhkan partisipasi aktif siswa, antusias, dan keceriaan dalam pembelajaran. Peneliti memberikan nasehat kepada siswa agar tidak ribut pada saat pembelajaran dan peneliti menanyakan apa cita-cita siswa dan bagaimana meraih cita-cita tersebut.

Ketiga skor kemajuan individu dan skor kelompok di peroleh data skor kemajuan individu dan kelompok kurang memuaskan, hal ini dikarenakan siswa masih sering ribut dan mengerjakan LKS secara individu, peneliti memberikan penjelasan mengenai berkerja kelompok.

Keempat motivasi belajar siswa siswa cukup senang terhadap pembelajaran IPA dengan perolehan ketuntasan 62,5\%. Hal ini disebabkan kondisi tempat tinggal siswa di wilayah pesisir yang mengakitbatkan siswa lebih memilih berkerja membantu nelayan dari pada belajar di rumah. Kemudian peneliti memberikan nasehat kepada siswa bahwa pada anak usia dini dilarang bekerja dan diwajibkan untuk belajar.

Kelima pada aspek kognitif, siswa belum menguasai materi siklus daur air sehingga hasil belajar siswa masih rendah dengan perolehan ketuntasan kognitif 56,25\%. Hal ini disebabkan masih banyak siswa yang tidak memperhatian penjelasan yang disampaikan, maka peneliti memberikan nasehat untuk memperhatiakan penjelasan dari guru karena jika tidak memperhatikan penjelasan guru nanti tidak bisa memahami materi yang telah disampaikan.

Keenam pada aspek afektif, terdapat beberapa siswa yang kurang dan belum mampu menunjukan sikap menerima saat guru menjelaskan materi pembelajaran, tidak menaggapi pendapat yang disampaikan oleh teman kelompoknya pada saat diskusi dan tidak menghargai pendapat yang disampaikan oleh teman kelompoknya pada saat diskusi. Siswa kurang mengatur dalam diskusi kelompok sehingga masih banyak siswa yang berbicara tidak sesuai pokok bahasan dalam diskusi, karakteristik siswa kurang disiplin saat diskusi kelompok sehingga keadaan kelas kurang kondusif.

Ketujuh pada aspek psikomotorik, terdapat beberapa siswa saat menggambar siklus daur air masih banyak yang tidak sesuai dengan yang sudah di jelaskan oleh guru, teknik menggambar siswa dalam menggabar siklus daur air kurang rapi. Selain itu siswa harus lebih berlatih untuk menggambar proses daur air.

Berdasarkan hasil pengamatan aktivitas siswa, aktivitas guru, motivasi belajar siswa serta hasil belajar IPA pada ketiga aspek (kognitif, afektif dan psikomotorik) pada siklus I maka wajib dilanjutkan ke 
siklus II untuk perbaikan sehingga akan mendapatkan motivasi dan hasil belajar siswa yang lebih baik lagi.

Pada tahap refleksi siklus II ini, peneliti berdiskusi dengan pengamat untuk membahas kembali hasil evaluasi dalam dua pertemuan tentang proses pembelajaran untuk hasil pembelajaran yang telah dilaksanakan. Dari hasil yang diperoleh, aktivitas siswa, aktivitas guru, motivasi belajar dan hasil belajar siswa (aspek kognitif, aspek afektif, dan aspek psikomotorik) sudah lebih baik. Pada siklus II siswa sudah terlihat dapat menunjukkan lima aspek yaitu menerima, menanggapi, menghargai, mengatur, karakteristik. Siswa juga sudah terlihat dapat menggambar siklus daur air dan teknik penyambungan pipa air. Kemudian pada aktivitas siswa sudah terlihat bahwa siswa telah aktif dalam membawa perlengkapan patuh dan tertip, mengamati demonstrasi dan mengikuti pembelajaran dengan serius, aktif mengajukan pertanyaan kepada guru, aktif dalam mengerjakan LKS secara individu maupun kelompok, perkembangan aktivitas siswa dapat dilihat dari hasil pengamatan pakda siklus I 68\% pada siklus II meningkat menjadi 83\%. Pada aktivitas guru, guru mampu membuat siswa menjadi antusisas dan menumbuhkan keceriaan yang tinggi saat proses pembelajaran berlangsung, mampu mengelola kelas dengan baik, perkembangan aktivitas guru dapat di lihat dari hasil pengamatan siklus I 68\% pada siklus II meningkat menjadi 87\%. Pada awal pembelajaran siswa kurang termotivasi untuk pembelajaran IPA setelah di berikan motivasi dalam bentuk Verbal dan menjelaskan bagaimana meraih cita-cita siswa, kemudia motivasi belajar siswa menjadi meningkat, perkembangan motivasi belajar siswa dapat dilihat dari angket motivasi yang di isi oleh siswa pada siklus I 62,5\% siklus II meningkat menjadi 84,375\%. Peningkatan hasil belajar siswa kelas V B SDN 047 Tarakan dari siklus I ke siklus II sebagai berikut:

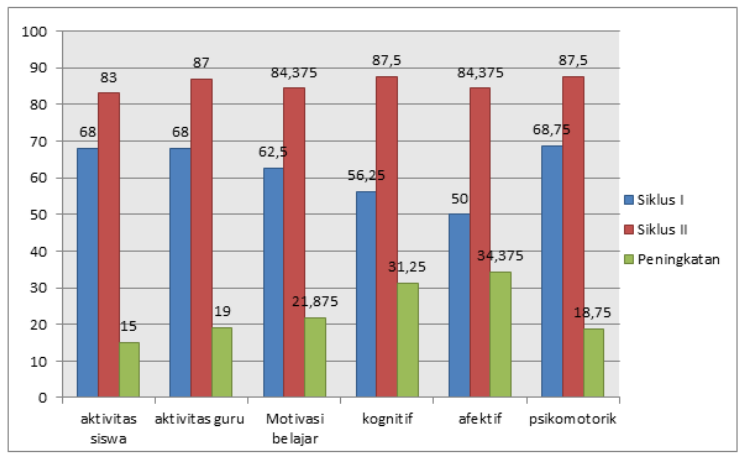

\section{Grafik 1. Data Hasil Peningkatan Indikator Tiap Siklus}

Berdasarkan grafik hasil peningkatan indikator tiap siklus diperoleh data Pengamatan aktivitas siswa siklus I sebesar 68\% kemudian si siklus II sebesar 83\%, sehingga peningkatan dari siklus I ke siklus II pada Pengamatan aktivitas siswa sebesar 15\%. Pengamatan aktivitas guru siklus I sebesar $68 \%$ kemudian si siklus II sebesar 87\%, sehingga peningkatan dari siklus I ke siklus II pada aspek kognitif sebesar 19\%. Motivasi belajar siwa siklus I sebesar 62,5\% kemudian si siklus II sebesar $84,375 \%$, sehingga peningkatan dari siklus I ke siklus II pada Motivasi belajar sebesar 21,875\%. Pada aspek Kognitif siswa siklus I sebesar 56,25\% kemudian si siklus II sebesar 87,5\%, sehingga peningkatan dari siklus I ke siklus II pada aspek kognitif sebesar 31,25\%. Pada aspek Afektif siswa siklus I sebesar 50\% kemudian si siklus II sebesar 84,375\%, sehingga peningkatan dari siklus I ke siklus II pada aspek Afektif sebesar 34,375\%. Pada aspek Psikomotorik siswa siklus I sebesar 68,75\% kemudian si siklus II sebesar 87,5\%, sehingga peningkatan dari siklus I ke siklus II pada aspek Psikomotorik sebesar 18,75\%

\section{KESIMPULAN}

Peneliti telah melaksnakan empat prosedur penelitian tindakan kelas yaitu perencanaan, pelaksanaan, observasi, dan refleksi, peneliti mendapatkan data motivasi dan hasil belajar, yang disajikan sebagai berikut: 1). Motivasi belajar, Motivasi belajar siwa siklus I sebesar 62,5\% kemudian si siklus II sebesar 84,375\%, sehingga peningkatan dari siklus I ke siklus II pada Motivasi belajar sebesar 21,875\%, 2) Hasil belajar, pada aspek Kognitif siswa siklus I sebesar 56,25\% kemudian si siklus II sebesar $87,5 \%$, sehingga peningkatan dari siklus I ke siklus II pada aspek kognitif sebesar 31,25\%. Pada aspek Afektif 
siswa siklus I sebesar 50\% kemudian si siklus II sebesar 84,375\%, sehingga peningkatan dari siklus I ke siklus II pada aspek Afektif sebesar 34,375\%. Pada aspek Psikomotorik siswa siklus I sebesar 68,75\% kemudian si siklus II sebesar 87,5\%, sehingga peningkatan dari siklus I ke siklus II pada aspek Psikomotorik sebesar 18,75\%.

Dari hasil penelitian dan pembahasan dapat disimpulkan bahwa penerapan model pembelajaran kooperatif tipe Student Team Achievement Divisions (STAD). dapat meningkatkan Motivasi dan hasil belajar Ilmu Pengetahuan Alam pada siswa kelas V B SDN 047 Tarakan semester ganjil tahun pembelajaran 2016/2017

\section{DAFTAR PUSTAKA}

Arends, Richard I. 2013. Belajar untuk mengajar. Jakarta: Salemba Humanika.

Arikunto, Suharsimi. 2015. Dasar-Dasar Evaluasi Pendidikan. Yogyakarta: PT Pustaka Pelajar.

Asep, Jihad. 2012. Evaluasi Pembelajaran. Yogyakarta: Multi Pressindo.

Sardiman. 2014. Interaksi Dan Motivasi Belajar Mengajar. Depok: Rajagafindo Persada.

Shoimin, Aris. 2016. 68 Model Pembelajaran inovatif dalam kurikulum 2013. Yogyakarta: AR-Ruzz Media.

Purwanto. 2013. Evaluasi Hasil Belajar. Yogyakarta: Pustaka Pelajar. 